\title{
Yerel Yönetimlerce Engellilere Sunulan İstihdam Hizmetleri: İstanbul Büyükşehir Belediyesi Engelliler Müdürlüğü Örneği
}

\section{Employment Services Provided to Disabled by Local Governments: Case of Istanbul Metropolitan Municipality Directorate of Disabled People}

\author{
Yaşar $\operatorname{Tınar}^{1}$ (1)
}

Öz

Sosyal bir varlık olan ve toplum içerisinde yaşayan insan, çaba göstererek ve üreterek içinde bulunduğu topluma faydalı olmayı istemektedir. Bilindiği üzere çalışmayı ve üretmeyi her insan arzu etmektedir. Ayrıca iş gücüne katılma her insanın da hakkıdır. Engellilerin istihdamı adına ortaya konulacak her türlü çalışma ve çözümler ile birlikte engellilerin çalışma haklarına kavuşmaları, toplumla olan adaptasyonları açısından oldukça önemlidir. Çalışmak ve üretmekle birlikte insanlar, ekonomik ihtiyaçlarının yanı sıra sosyal intiyaçlarının da karşılanmasını istemektedir. Gerek özel sektörün gerekse kamu sektörünün engellileri istihdam ederek ülke ekonomisine katkısının büyük olacağından hiç şüphe yoktur. Bu çalışmada yerel yönetimlerin dezavantajı vatandaşlara imkan ve olanaklar dahilinde sunduğu engelli istihdamının İstanbul Büyükşehir Belediyesi Engelliler Müdürlüğü örneği üzerinde durulmuştur.

Anahtar Kelimeler

Engelli, İstihdam, Yerel yönetimler, Engelliler mMüdürlüğü, İstanbul büyükşehir belediyesi

\begin{abstract}
The human being, who is a social entity and lives in the society, wants to benefit the society people live in by making efforts and producing. Every human being wants to work and produce. In addition, the right to work is the right of every person. It is very important that all kinds of work and solutions be put forward in the name of the employment of disabled people to have the right to work and adapt to society. In addition to working and producing, people ensure that their social needs as well as their economic needs are met. There is no doubt that both the private sector and the public sector will contribute greatly to the national economy by employing disabled people. In this article, the example of the Istanbul Metropolitan Municipality Directorate of Disabled People, which is provided by the local administrations to the disadvantaged citizens within the scope of opportunities, is emphasized.
\end{abstract}

\section{Keywords}

Disabled, Employment, Local governments, Directorate of disability, Istanbul metropolitan municipality

1 Sorumlu Yazar: Yaşar Tınar (Dr.), Sultangazi Belediyesi Kültür ve Sosyal İşler Müdürlüğü, İstanbul, Türkiye. E-posta: yasartinar@sultangazi.bel.tr ORCID: 0000-0002-2382-4833

Attf: Tinar, Y. (2020). Yerel Yönetimlerce Engellilere Sunulan İstihdam Hizmetleri: İstanbul Büyükşehir Belediyesi Engelliler Müdürlüğü Örneği. Sosyal Siyaset Konferansları Dergisi, 78: 429-453. https://doi.org/10.26650/jspc.2020.78.0011 


\section{Extended Summary}

Disability refers to a number of deficiencies, either physically or mentally, as well as difficulties in the participation or adaptation to social life. That is, disabilities prevent the individual from fulfilling his/her duties in social and business life.

Like every human being living in society, people with disabilities endeavor to produce and develop themselves. Together with working and producing, people not only meet their economic needs but also their social needs. Therefore, people with disabilities who are looking for a job can work either in the public or private sector.

The fact that a person has a disability does not require him/her to give up or be hindered from his/her working life and right to work. Because, like all individuals, people with disabilities must meet their daily needs and health expenses. Thus, people with disabilities will not only be consuming but also producing. If a person with a disability is placed in a job suitable for his/ her qualification, education and disability, he/she will also feel confident, in addition to facilitating his/her daily life and meeting his/her needs. In addition, facilitating the lives of disadvantaged groups is the basic principle of being a social state and a social municipality.

The Istanbul Metropolitan Municipality Directorate of Disabled People has a wide service network and infrastructure in terms of services for the disabled. The Directorate of Disabled People contacts 700 companies annually on the subject of employment of disabled people, and provides employment to 400 people with disabilities. Thus, it contributes to the employment policies of Turkey and Istanbul. In this context, when the services for disabled people are evaluated, the Directorate of Disabled People ensures the participation of the disabled people in social life, increases their self-confidence and helps them to have a social status.

As in many developed countries, Turkey has necessary legal laws and arrangements on the employment of disabled people, such as kind of businesses, rights, work and social adaptation, and vocational training, etc.. Employment laws for disabled vary somehow from one country to another, but there are many similarities. All legal arrangements for the employment of disabled have been guaranteed under the law enacted by the Turkish Grand National Assembly, and are identified as below. 
For the first time in 1986, a council recommendation was made on the employment of persons with disabilities at the European Community level. Again in 1997, the "European Employment Strategy" was adopted. In this context, a "National Action Plan for Employment" was requested from the member countries. It is also expected that job opportunities, including groups of people with disabilities, will be explored, and efforts will be made to improve the work skills of people with disabilities. In 2000, the European Commission issued the "Equal Treatment of Employment and Work" directive. With this directive, all kinds of discrimination were challenged. It is emphasized that if a regulation on the work environment of the disabled individual is issued, the disabled individual may be suitable for the job.

In Turkey, according to Article 30 of the 4857 Act; employers are obliged to employ $\% 3$ disabled people in private sector work places where they employ fifty or more workers. According to the same article, individuals are obliged to work in jobs that are appropriate to their occupational, physical and mental status. According to the Civil Servants Law No. 657; public institutions and organizations are obliged to employ disabled people in their staff. The obligation to employ disabled people in the public institutions and organizations with fifty or more employees is $4 \%$.

As a result of the discussions and researches on how, in what conditions and under what conditions the persons with disabilities brought about by the legal obligations regarding the employment of persons with disabilities, various methods of employment of persons with disabilities have emerged. Because, when the literature studies and researches are examined, it can be seen that there are seven different methods of employment for the disabled. These seven different methods of employment for the disabled are: The Quota System Consists of Protected Workplaces, Personal Working Methods, Employers' Employability without Obligation, Working at Home, Cooperative Working Methods and Employment Method in Selected Jobs, where only Disabled People are Employed.

The Istanbul Municipality Directorate of Persons with Disabilities first invites the disabled to apply for employment. A face-to-face interview is held with the disabled person, who comes to the employment office upon invitation. These interviews are usually conducted with psychologists. A resume pool is formed by psychologists filling in the resumes of the disabled. Essentially, 
the aim is to find out what qualifications are required by the employers. The qualified resumes are called for interviews according to the qualifications demanded by employers. In this way, employers have interviews with disabled people who can work in their own positions. In other words, they do not meet the staff who cannot meet their needs. Thus, employers do not have to waste time unnecessarily interviewing people with disabilities. Therefore, due to this classification of resumes, private sector workplaces generally apply directly to the Directorate of Persons with Disabilities for the employment of persons with disabilities.

As mentioned above, the Directorate of Disabled People not only organizes private sector employer and employee meetings, but also organizes for free the disabled public personnel selection exam (E-KPSS) courses for the disabled. Thus, people with disabilities who attend the courses are better equipped and prepared for the examinations organized and conducted by the state. Candidates who take the exam as a result of the courses can become civil servants if they pass the exam. As can be seen, the Istanbul Metropolitan Municipality Directorate of Disabled People carries out its activities in a multi-dimensional manner in order to enable disabled people to work in both the private and public sectors. 


\section{Yerel Yönetimlerce Engellilere Sunulan İstihdam Hizmetleri: İstanbul Büyükşehir Belediyesi Engelliler Müdürlüğü Örneği}

Engellilik, bedensel veya zihinsel olarak birtakım eksikliklerin yanı sıra aynı zamanda sosyal hayata katılımda veya uyum sağlamada yaşanan zorlukları ifade etmektedir. Yani engellilik hali, bireyin sosyal hayatta veya yaşamdaki vazifelerini yerine getirmesini engellemektedir. 1950'li y1llardan sonra daha da belirgin hal alan engellilik olgusu, ilk zamanlarda sadece zorunlu istihdam politikalarıyla ilişkilendirilmiştir. Fakat daha sonraki süreç içerisinde sosyal devlet anlayışının gelişmesiyle birlikte engellilik alanındaki çalışmalar daha bütüncül bir yaklaşımla sosyal hayatın bütününü kapsayacak şekilde genişlemiştir.

Çalışma, bir işe yerleşme, üretime katılma durumu yalnızca belirli bir gelir elde etmenin haricinde her bir birey için sosyal hayata katılımın vazgeçilmez bir unsurudur. Böylece bir kişinin engelli olması onu çalışma hayatından ve bu haktan vazgeçmesini veya geçirilmesini gerektirmemektedir. Esasen engelli bireylerin istihdam edilmeye diğer insanlara nazaran daha fazla ihtiyaçları bulunmaktadır. Çünkü engelli bireylerin her bir birey gibi günlük ihtiyaçlarını ve sağlık giderlerini karşılaması gerekmektedir. Böylece engelli bireyler sadece tüketen değil aynı zamanda üreten konumuna da geçmiş olacaklardır. Eğer engelli bir birey eğitimine ve engel durumuna uygun bir işe yerleşirse günlük hayatını kolaylaştırmanın ve ihtiyaçlarını karşılamanın dışında kendine ayrıca özgüven duyacaktır. Bütün bunların yanı sıra dezavantajlı grupların hayatını kolaylaştırmak ve onların ihtiyaçlarını gidermek sosyal devlet ve sosyal bir belediye olmanın temel prensiplerindendir. Nitekim bu alanda gerek devletler gerekse belediyeler birçok düzenleme, çalışma ve proje yapmıştır ve yapmaya devam etmektedir.

Uluslararası Çalışma Örgütüne göre, dünya nüfusunun tahminen \%15'ini engelliler oluşturmaktadır. Bu engelli nüfusun ise ortalama \%80'i çalışma çağında bulunmaktadır. Maalesef engelli çalışanlar, özellikle kadın çalışanlar, iş dünyasında firsat eşitliği ilkesinden yeterince yararlanamamaktadır. Ayrıca dünya genelinde engellilerin genellikle yoksullukla, işsizlikle ve sosyal korumadan mahrum olarak yaşadığı da bilinmektedir. https://www.ilo. org/global/topics/disability-and-work/WCMS_475650/lang--en/index.htm (19.12.2019). 
İstanbul Büyükşehir Belediyesi Engelliler Müdürlüğü, engelli hizmetleri açısından geniş bir hizmet ağına ve alt yapısına sahiptir. Bu anlamda müdürlük olarak engellilere yönelik İstanbul genelinde hizmet etmektedir. Ulaşımdan spora, eğitimden kamp hizmetlerine, sosyal destek hizmetlerinden yasal haklar danışmanlığına kadar bir çok hizmeti profesyonel bir şekilde yürütmekte ve engelliler ile ailelerine sunmaktadır. Engelliler Müdürlüğü, ki aşağıda belirtilen istatistiki veriler bizzat müdürlükten resmi yazı ile temin edilmiştir, özel olarak engelli istihdamı konusunda yılda ortalama 700 firmayla irtibat kurup yine y1lda ortalama 350-400 engelliyi işverenlerle buluşturup engellilerin istihdamını sağlamaktadır. Böylece Türkiye'nin ve İstanbul'un istihdam politikalarına katkı sağlamaktadır. Bu çerçevede engelli hizmetleri değerlendirildiğinde Engelliler Müdürlüğü, engellilerin istihdamının yanı sıra onların sosyal hayata katılımlarını sağlamakta, kendilerine olan özgüvenlerini artırmakta ve sosyal bir statüye kavuşmalarını sağlamaktadır.

\section{Engellilik Kavramı ve Türleri}

Kişisel ve çevresel faktörlerin yanı sıra kişinin bedenen ve ruhen sağlık durumu engellilik kavramı üzerinde oldukça önem arz etmektedir. Genel olarak bakıldığında engellilik konusu mevzu bahis ise görme, işitme veya ortopedik engelliler ilk olarak akla gelmekte ve engelli kategorisini oluşturmaktadırlar. Gerçek anlamda engellilik olgusu heterojen bir yapıya sahip olmakla birlikte örneğin; nasıl bir asker mayına basmış ve bu olay neticesinde ayağını kaybedip engelli kalmışsa, yine doğum sırasında meydana gelen ve kişinin üzerinde herhangi bir olumsuzluktan dolayı fiziksel bir kaybın oluşması da engelliliği aynı şekilde açıklamaktadır.

Engellilik süresince kişilerin sağlık durumu değişkenlik gösterebilmektedir. Nitekim engellilik geçici veya uzun süreli olabileceği gibi, ağrılı veya ağrısız da olabilmektedir. Yine aynı şekilde engellilik olgusu görünür veya görünmez olarak karşımıza çıkabilmektedir. Burada asıl önemli olan konu engelli bireyin kendisini sağlık bakımından çoğunlukla iyi hissedememesidir. Ayrıca, engellilik üzerinde yapılan genellemelerden yola çıkılarak yapılan yönlendirmeler de her zaman doğruyu gösteremeyebilir. Zira engelli kişiler arasında yaş, cinsiyet, kültür, cinsellik, sosyal ve ekonomik durum ve etnik köken bakımından farklılıklar bulunmaktadır. (WHO, 2011, s.8). 
Dünyada ve Türkiye'de en çok bilinen ve tanımlanan engellilik türleri arasında; Zihinsel Engelliler, Ortopedik Engelliler, Süreğen Engelliler, Görme Engelliler, İşitme Engelliler, Otizmliler ve Konuşma Engelliler bulunmaktadır. (İBB, 2012, s. 504-507).

Engellilik konusu farklı boyutları olan ve tartışmaya açık konulardan birisini oluşturmaktadır. Bundan dolayı geçmişten günümüze sağlık ve sosyal hizmet alanlarında çalışan araştırmacılar sosyal veya fiziksel engellerin engellilik üzerindeki rolünü tespit etmeye çalışmışlardır. Yani tarihsel süreç içerisinde engellilik olgusu bireysel tıbbi modelden toplum tarafından insanların engelli konuma getirildiği sosyal modele geçiş olarak tanımlanmıştır. (WHO, 2011, s.3-4). Daha önceleri engellilik kavramına fiziksel bir olay olarak bakılmış ve sonraki süreçte ise engellilerin sosyal anlamda toplumdan dışlanmaları, ötekileştirilmeleri, rehabilite edilememeleri gibi sorunlar üzerinde durulmuştur. Yine de engelliliğe yalnızca tıbbi veya sosyal açıdan bakmanın doğru olmayacağı gibi iki farklı görüşün arasında bir denge sağlanması da gerekmektedir. Zira gerçek anlamda engellilik kavramının açıklanabilmesi için psikolojik, sosyolojik ve biyolojik olmak üzere üç farklı alan üzerinde etkileşim kurulması gerekmektedir. Çünkü, engellilik olgusu, bireyi günlük hayattaki aktivelerinde kısıtlamaya götürmekte, bireyi bu aktivitelerde yetersiz k1lmakta ve bireyin toplumla olan sosyal ilişkisinde sınırlama getirmektedir. Ayrıca engellilik olgusu, bireye ait çevresel ve kişisel olumsuzluklara da değinmektedir.

Engellilik, kavram olarak farklı kaynaklarda farklı şekilde ifade edilmesine rağmen en çok kullanılan kavramlar arasında; "sakat”, "özürlü” ve "engelli” tanımları yer almaktadır. Engellilerle alakalı farklı ifadelerin var olması sadece Türkçe'ye özgü olmayıp, pek çok dilde de aynı problemin yaşandığı bilinmektedir. Örneğin, Türkçe'de özürlü, sakat ve engelli ifadeleri farklı anlamlar taşımış olsalar dahi genel itibariyle aynı anlamda kullanılmaktadırlar. (Öztürk, 2011, s.19). Bu açıdan engelli kavramının genel geçer bir tanımının yapılması oldukça zor görünmektedir. Yine bu konuyla alakalı olarak literatürde değişik tanımların ve ifadelerin yapıldı̆̆ 1 da bilinmektedir. Örneğin; Birleşmiş Milletler Sakat Hakları Bildirgesine göre engelli birey: "Kişisel ya da sosyal yaşantısında kendi kendisine yapması gereken işleri herhangi bir noksanlık sonucu (bedensel ya da sonradan olma) yapamayanlar" olarak ifade edilmiştir. Bununla birlikte engellilik konusu ve anlayışı da ülkeden ülkeye 
farklılık gösterebilmektedir. Örneğin; Almanya bu konuda diğer ülkelere göre daha esnek bir yapıya sahiptir. Çünkü, Almanya'da kalp krizi geçiren bir kişi en az iki yıl süreyle ağır engelli sınıfına girmektedir. (Çınar, 2010, s. 5).

Engelli sözcüğü genel anlamda bir hareket yeteneğinin kısıtlanmasını öngörmektedir. Bu hareket kısitlılığı doğum öncesi olabileceği gibi doğum esnasında veya doğum sonrasında da meydana gelebilmektedir. (Öztürk, 2011, s. 20). Engelliliğin tanımı yapılırken bir takım unsurların da dikkate alınması gerekmektedir. Bilhassa sosyal unsurlar engelli tanımı için oldukça önem arz etmektedir. Bu sosyal unsurları ise, çalışmaya elverişlilik, erişebilirlik, sosyal hayata uyumun sağlanması, ulaşım probleminin ortadan kaldırılması, bakıma muhtaç olma gibi durumlar ifade etmektedir.

Dünya Sağlık Örgütü, engelliliği daha çok hastalıktan gelen sebeplere ağırlık vererek tanımlamıştır. Bu tanımlamayı ise üç farklı gruba ayırmıştır. Bu üç farklı tanımlamadan ilkini "yetersizlik”, ikincisini “özürlülük”, üçüncüsünü ise "engellilik" oluşturmaktadır. Yetersizlik, sağlık bakımından bir eksikliği ortaya koymaktadır. Yani psikolojik, fiziksel yap1 ve fonksiyonlarda bir eksikliği ifade etmektedir. Özürlülük, herhangi bir sakatlık sonucundan dolayı sağlıkı bir insanın yapabileceği bir işi yerine getirememesini ifade etmektedir. Engellilik ise, herhangi bir sakatlık veya eksiklik sonucunda meydana gelen ve o kişinin cinsiyet, yaş ve sosyo-kültürel durumuna göre normal kabul edilebilecek bir işi yerine getirmesini önleyen veya onu kısıtlayan olumsuz bir durumu göstermektedir.

Tablo 1

Dünya Sağlık Örgütünce Yapılmış Engellilik Tanımları

\begin{tabular}{lcc}
\hline Yetersizlik (Impairment) & Özürlülük (Disability) & Engellilik (Handicap) \\
\hline Kesik Bacak & Yürüme Güçlüğü & Isssizlik \\
Görme Bozukluğu & Okuma Güçlüğü & Okula Devam Edememe \\
Kol veya Bacaktaki Felç & Sinırlı Hareket & Sosyal Soyutlanma \\
İşitme Bozukluğu & Konuşulanları Anlamada Güçlük & Sosyal Soyutlanma \\
Zihinsel Bozukluk & Yavaş Öğrenme & Sosyal Soyutlanma \\
\hline
\end{tabular}

Kaynak: Nevruz Çınar, Üniversite Kampüslerindeki Peyzaj Erişebilirliğinin Engelliler Açısından İrdelenmesi, Basılmamış Yüksek Lisans Tezi, Ankara, Ankara Üniversitesi Fen Bilimleri Enstitüsü, 2010, s. 6.

\section{Sosyal Politika Açısından Yerel Yönetimler}

Yerel yönetimler; yereldeki halkın ihtiyaçlarını karşılamak üzere, yereldeki topluluğa kamu hizmeti sunan ve yereldeki halkın kendi iradesi ile seçtiği organlarca yönetilen; yönetsel ve siyasal kurumları ifade etmektedir. Yerel 
yönetimlerin varlık nedenleri arasında; halkın güven ve desteğinin sağlanması, çoğulcu ve demokratik yönetim anlayışının benimsenmesi ve halkın istek, öneri ve şikayetlerinin ön planda tutulması bulunmaktadır. Bundan dolayı yerel yönetimler, yereldeki halkın müşterek gereksinimlerinin karşılanması için oluşturulan, karar organlarını halkın seçtiği, demokratik, özerk bir yönetimi olan kamu birimleri olarak tanımlanabilmektedir. Nitekim yerel yönetimlerin devlete ait tüzel kişiliğinin yanında kendine özgü bir tüzel kişiliği, malvarlığ ve gelir kaynağı bulunmaktadır. (Henden, B., Henden, R., 2005, s. 50).

Yerel yönetimler, bir hizmetin gerçekleşmesinde mutlaka sunulan hizmet için bir yasal dayanak ararlar. Bu açıdan yerel yönetimler için "5216 sayılı Büyükşehir Belediye Kanunu”, "5393 sayılı Belediye Kanunu” ve "5018 sayılı Kamu Mali Yönetimi ve Kontrol Kanunu” oldukça önemlidir. Öyle ki, yerel yönetimler dezavantajlı kesimler için yapacağı çalışmaları da ilgili kanun maddelerine göre yapmaktadır. Bilindiği üzere 5216 sayılı Büyükşehir Belediyesi Kanunu'nun 7. maddesi yerel yönetimlere; hastane, sağlık merkezleri ve gezici sağlık üniteleri açmak; yaşlılar, yetişkinler, gençler, kadınlar, çocuklar ve engellileri kapsayan her çeşit sosyal ve kültürel faaliyeti gerçekleştirmek; sosyal tesisler oluşturmak; kişisel ve mesleki kurslar açmak; üniversiteler, yüksek okullar ve sivil toplum kuruluşlarıyla iş birliği içerisinde olmak gibi yetkiler vermiştir. Yine aynı kanunun 7. maddesine göre yerel yönetimler; yaşlılara, engellilere, kadınlara, gençlere ve çocuklara yönelik sosyal ve kültürel hizmet sunma görevini vermiştir. https://mevzuat.gov.tr/ mevzuatmetin/1.5.5216.pdf (28.01.2020).

5393 sayıl1 Belediye Kanunu'nun 38. maddesine göre yerel yönetimlerde belediye başkanının görev ve yetkileri arasında; bütçeden ihtiyaç sahiplerine ve yoksullara yardım yapmak; engelli merkezleri açmak ve engellilerle ilgili hizmetleri yürütmek bulunmaktadır. https://mevzuat.gov.tr/ mevzuatmetin/1.5.5393.pdf (28.01.2020).

Yerel yönetimlerin temel sosyal politika alanındaki işlevlerini; önleyici, koruyucu ve bütüncül sosyal politikalar üretmek, bölge halkının yatay ve dikey sosyal entegrasyonunu sağlamak, sosyal yardım ve hizmet politikalarını yürütmek ve adil bir gelir dağılımının sağlanması oluşturmaktadır. Ayrıca belediyelerin sosyal yönü ağır basan genel çalışmalar arasında; kimsesizlerin, muhtaçların, sokakta yaşayanların barınma ihtiyaçlarını karşılamak, kreş ve huzur evi açmak, sağlık merkezleri oluşturmak, kültür-sanat ve spor tesisleri 
açmak, aşevi kurmak, engellilere yönelik bütüncül politikalar oluşturmak, mesleki ve kişisel gelişim kursları açmak, park, bahçe ve piknik alanlarını yaygınlaştırmak, ucuz konut inşa etmek, ekmek fabrikası açmak, tanzim satış ofisleri kurmak ve ihtiyaçlar doğrultusunda ihtiyaç sahibi kişilere gıda, giyim ve kömür yardımı yapmak bulunmaktadır. (Güleç, 2014, s. 491).

\section{Türkiye'de Engelli İstihdamını Destekleyen ve Düzenleyen Yasal Düzenlemeler}

Türkiye'de ve dünyada engelli istihdamı yapılmakla birlikte engellilerin nasıl işe yerleştirilecekleri, ne şekilde istihdam edilecekleri, iş hayatında hangi hakları olduğu, iş ve sosyal hayata adaptasyonları, kişisel ve mesleki eğitimlerinin arttırılması gibi konular ülkeden ülkeye değişmekle birlikte engellilerin çalışma hakkı hukukun güvencesi altına alınarak yasal mevzuatlarla belirlenmiştir.

Engelli istihdamı konusunda 1986 y1lında ilk defa Avrupa Topluluğu seviyesinde "Konsey Tavsiye" kararıalındığıbilinmektedir. Alınan bu kararının önemini ise ilk defa engellilerin sosyo-ekonomik hayatla bütünleşmesini ve istihdam edilmelerine yönelik çalışmaların başlatılmış olması göstermektedir. Dolayısıyla, alınan kararla birlikte tüm üye devletlere engellilerin istihdamıyla ilgili bir politika oluşturulmasının önü açılmıştır.

Avrupa Birliği, engellilikle ilgili uluslararası düzeyde politikalarını Birleşmiş Milletlerin 1993 yılında kabul ettiği "Fırsat Eşitliği Konusunda Engelliler için Standart Kurallar İlke Kararı"na dayandırmaktadır. Yine 1997 yılında “Avrupa İstihdam Stratejisi”nin kabul edilmesi ve bu y1ldan sonra yıllık olarak düzenli bir şekilde hazırlanan konsey yönergelerinde de engellilikle ilgili konulara yer verildiği bilinmektedir. $\mathrm{Bu}$ çerçevede üye ülkelerden "İstihdama Yönelik Ulusal Eylem Planı" hazırlamaları istenmiştir. Ayrıca engelli grupları da dahil olmak kaydıyla iş olanaklarının araştırılması ve engellilerin iş yeteneklerini geliştirmeye yönelik gayret gösterilmesi üye ülkelerden beklenmiştir.

2000 yılında Avrupa Komisyonu tarafından çalışma hayatı ve engellilikle ilgili bir direktif verilmiş ve verilen bu direktife ise "İstihdamda ve İşte Eşit Muamele" denilmiştir. Bu direktifle birlikte her türlü ayrımcılığa karşı çıkılmıştır. Yani engellilere yönelik özel düzenlemeler yerine, engellilerin 
iş yerinde karşılaştıkları engellerin ortadan kaldırılması ve engellilerin yararlanmaları gereken haklardan diğer çalışanlar gibi eşit bir biçimde yararlanmaları istenmiştir. Kısacası, sorun yerine çözüm odaklı olma fikri ortaya çıkmıştır. Böylelikle, engelli kişinin çalışma ortamıyla ilgili bir düzenleme yapıldığı takdirde engelli kişinin o iş için uygun duruma gelebileceği vurgulanmak istenmiştir. Yani işe uygun aday yerine adaya uygun iş stratejisi benimsenmiştir. (Tiyek, 2014, s.107-108)

BM Genel Kurulu'nda 2006 yılında kabul edilen ve 2008 yılında yürürlüğe giren ve 2009 yılında Türkiye tarafından da uygun bulunup onaylanan "Engellilerin Haklarına ilişkin Sözleşme"de de engelli istihdamına yer verilmiştir. Bu sözleşme kapsamında taraf devletler, engellilerin de diğer bireyler gibi eşit koşullar altında çalışma hakkına sahip olduğunu kabul etmiş ve engellilerin, açık, bütünleştirici ve erişilebilir bir iş piyasası ve çalışma ortamında serbest olarak seçtikleri bir işle hayatlarını kazanmalarını sağlamışlardır. Ayrıca taraf devletler, çalışırken engelli olanlar da dahil olmak üzere tüm engellilerin çalışma hakkının yaşama geçmesini ve yasama çalışmalarını da içeren tüm tedbirleri alarak güvence altına almıştır. Yine "Engellilerin Haklarına İlişkin Sözleşme”ye göre, taraf devletler, engellilerin köle olarak tutulmalarını engeller ve engellileri zorla çalışmaya karşı diğer bireylerle aynı şekilde eşit olarak korurlar. https://humanrightscenter.bilgi. edu.tr/media/uploads/2015/08/03/EngellilerinHaklarinaIliskinSozlesme. pdf (18.12.2019). Tabii yine bu sözleşme dahilinde engellilerin istihdamıyla ilgili birçok olumlu görüş ifade edilmiştir. Örnek olarak, engellilerin kamu kurumlarında çalışabilmesi, engellilere yönelik mesleki rehabilitasyon hizmetlerinin yürütülmesi, engellilere yönelik girişimcilik firsatının tanınması, engellilerin sendikal haklarının olması, engellilerin kendi işlerini kurmalarını sağlayan teşvik programları vb. uygulamalar gösterilebilmektedir.

Türkiye'de ise 4857 sayılı İş Kanunu'nun 30. Maddesine göre; işverenler, elli veya daha fazla işçi çalıştırdıkları özel sektöre ait işyerlerinde yüzde üç oranında engelli çalıştırmak mecburiyetindedir. Yine aynı madde gereğince kişiler meslek, beden ve ruhi durumlarına uygun işlerde çalıştırılmakla yükümlüdür ifadesi bulunmaktadır. Ayrıca, engellilerin yer altı ve su altı işlerinde çalıştırılmaması hükümleri de aynı kanunla belirlenmiştir. Aynı zamanda işverenler çalıştırmakla yükümlü oldukları işçileri Türkiye İş Kurumu aracılığıyla işe alırlar ibaresi de kanunla belirlenmiştir. Bu kapsamda çalışacak 
olan işçilerin özellikleri, hangi işe yerleştirilecekleri, kişilerin işyerlerinde genel hükümler dışında onları kapsayacak özel çalışma ile mesleklere yöneltilmeleri, mesleki açıdan işverence nasıl işe alınacakları gibi tüm detaylar kanun ile belirlenmiştir. Eğer işverenler tarafından kanuna aykırı veya uymayan bir durum söz konusu olursa, yine aynı kanunun 101. Maddesi gereğince tahsil edilecek cezalar, engellilerin ve eski hükümlülerin kendi işini kurmaları, engellilerin iş bulmasını kolaylaştırıcı iş ve işlemlere, engellilerin işe yerleştirilmeleri, iş ve işyerine uyumun sağlanması gibi projelerde kullanılmaktadır. https://www. mevzuat.gov.tr/MevzuatMetin/1.5.4857.pdf (11.07.2019).

Türkiye'de 657 sayılı Devlet Memurları Kanununda da kamu kurum ve kuruluşlarında engellilerin nasıl istihdam edilecekleri, hangi şartlarda işe alınacakları, hangi koşullar altında çalışacakları gibi hususlar kanun maddeleriyle belirlenmiştir. Yine 657 Sayılı Devlet Memurları Kanununa göre, engelli personel çalıştırma yükümlülüğü kanunun 53. Maddesi'nde belirtilmiştir. 657 sayılı Devlet Memurları Kanunu'nun 53. Maddesine göre; kamu kurum ve kuruluşları çalıştırdıkları personele ait kadrolarda engelli çalıştırmak mecburiyetindedir ifadesi yer almaktadır. Bundan dolayı ilk defa devlet memuru olacak engelliler kendileri için açılan sınavlardan başarılı olmak kaydıyla veya kura usulüyle yapılacak yerleştirmelerle kamu kurum ve kuruluşlarına atanabilmektedirler. https://www.mevzuat.gov.tr/ MevzuatMetin/1.5.657.pdf (14.07.2019).

Merkezi sınav öncesi engellilerin devlet memurluğuna yerleştirilmesi ilk olarak 1983 yılında gerçekleşmiştir. Çünkü 1983 yılında "Sakatların Devlet Memurluğuna Alınma Şartları ile Hangi İşlerde Çalıştırılacakları Hakkında Yönetmelik" çıkartılmıştır. Fakat 657 Sayılı Devlet Memurları Kanunu'nun 53. Maddesi'nde 2011 yılında bir değişiklik yapılmış ve yapılan değişiklikle birlikte engelli memur istihdamında merkezi sınav ve merkezi yerleştirme sistemine geçilmiştir. $\mathrm{Bu}$ değişiklikle birlikte engelli memur istihdamı konusunda köklü bir değişim yapıldığı görülmektedir. Ayrıca yapılan bu değişikle birlikte 2004 yılında yürürlüğe giren “Özürlülerin Devlet Memurluğuna Alınma Şartları ile Yapılacak Merkezi Sınav ve Kura Usulü Hakkında Yönetmelik”te yürürlükten kalkmıştır. Bütün bu gelişmelerle birlikte yeni yönetmelikte iki farklı sistem olduğu da bilinmektedir. Bu iki farklı sistemin ilkini kura sistemi ikincisini ise EKPSS oluşturmaktadır. (Kocabaş, 2018, s.69-71) 
Engellilerin istihdamıyla ilgili bir diğer kanun 5378 sayılı “Özürlüler ve Bazı Kanun ve Kanun Hükmünde Kararnamelerde Değişiklik Yapılması Hakkında Kanun”dur. Bu kanunla birlikte engellilerin çalışma hayatına ilişkin bazı ilke ve kurallar getirilmiştir. 5378 sayılı Kanun'un 14. Maddesi'nde; "işe alımda; iş seçiminden, başvuru formları, iş seçim süreci, teknik değerlendirme, önerilen çalışma süreleri ve şartlarına kadar olan safhaların hiçbirisinde engellilerin aleyhine ayrımcı uygulamalarda bulunulmaz" ifadesi bulunmaktadır. Yine 14. Madde'nin üçüncü fikrası'nda; “çalışan veya iş başvurusunda bulunan engellilerin karşılaşabileceği engel ve güçlükleri azaltmaya veya ortadan kaldırmaya yönelik istihdam süreçlerindeki önlemlerin alınması ve işyerinde fiziksel düzenlemelerin bu konuda görev, yetki ve sorumluluğu bulunan kurum ve kuruluşlarla işyerleri tarafından yaptırılması zorunludur” ifadesi yer almaktadır. (Mamatoğlu, 2015, s. 531-532).

Türkiye'de gerek belediyeler açısından gerekse diğer kurum ve kuruluşlar tarafından engelli istihdamı konusunda birçok düzenleme yapıldığı bilinmektedir. Yine bu düzenlemelerden bir tanesini de 572 say1l Kanun Hükmünde Kararname'nin 4. maddesi oluşturmaktadır. Kararname ile belediyelere çeşitli sorumluluklar yüklenmiş ve denmiştir ki; belediyeler, dezavantajlı grupların yaşamını kolaylaştıracak hizmetler sunacaktır. Ayrıca bu kanunla birlikte belediyelere çeşitli çalışmalar için kurum ve kuruluşlarla işbirliği yapmak, dezavantajlı gruplar için bölgenin işgücü piyasasına uygun mesleklerde meslek kursları açmak ve iş eğitimleri ile yaşam evleri açmak işlevleri verilmiş ve Türkiye'de engelli istihdamının öneminin ve ciddiyetinin anlaşılmasıyla beraber 2004 yılında Başbakanlık tarafından "2005-2010 Engelli İstihdam Eylem Planı” hazırlanmıştır. Yine, "Büyükşehir Belediyeleri Engelli Hizmet Birimleri Yönetmeliğì" başlığıyla 26261 sayılı Resmi Gazete'de yayımlanan çalışma esasları ve görevleri belirleyen yönetmelikle birlikte Büyükşehir Belediyelerine; mesleki rehabilitasyon hizmetleri vermesi, yapılan çalışmaları koordine etmesi ve engellileri çalışma yaşamına hazırlamak görevleri tevdi edilmiştir. (Tiyek, 2014, s. 109).

Aile, Çalışma ve Sosyal Hizmetler Bakanlığı'na bağlı Engelli ve Yaş1ı Hizmetleri Genel Müdürlüğü de engelli istihdamına yönelik çalışmalar yapmaktadır. Bu çalışmaların başında "Ulusal İstihdam Stratejisi” örnek gösterilebilir. Söz konusu “Ulusal İstihdam Stratejisi ve Eylem Planı”na göre, özel politika gerektiren grupların istihdamının arttırılması temel politika ekseni 
kapsamında engellilerin iş gücüne katılım oranı ve istihdamının arttırılmasına yönelik tedbirlerin alındığı bilinmektedir. Ayrıca bakanlığın engelli istihdamına yönelik çalışmalarında kurumlar arası işbirliğine önem verdiği bir gerçektir. "Ulusal İstihdam Stratejisi ve Eylem Planı" kapsamında izleme ve değerlendirme toplantıları, "Özel Politika Gerektiren Grupların İstihdamının Arttırılması Temel Politika Ekseni”ne ait alt kuruluşların oluşturulması ve engelli istihdamına yönelik çalıştay programları gerçekleştirmiştir. (T.C. Aile ve Sosyal Politikalar Bakanlığı, 2016, s. 103).

Engelli ve Yaşlı Hizmetleri Genel Müdürlügü̆’nün engelli istihdamına yönelik görevleri arasında; engellilerin toplumsal hayata katılımını ve istihdamına yönelik çalışmaları yapmak, koruyucu, önleyici, geliştirici ve yasal mevzuat ve uygulamaları düzenleyici ve uygulayıcı çalışmaları gerçekleştirmek ve ulusal düzeyde politika ve strateji oluşturmak gibi çalışmalar bulunmaktadır.

\section{Engelli İstihdam Yöntemleri}

Engellilerin istihdam edilmeleri konusundaki yasal zorunluluklar ile birlikte bu yasal zorunlulukların getirmiş olduğu engellilerin nasıl, ne şekilde ve ne şartlarda istihdam edilebileceklerine dair tartışmalar ve araştırmalar neticesinde zamanla çeşitli engelli istihdam yöntemleri oluşmuştur. Zira literatür araştırmalarına bakıldığında yedi farklı engelli istihdam yöntemi olduğu görülmektedir. Bu yedi farklı engelli istihdam yöntemini sırasıyla; Kota Sistemi, Korumalı İş Yerleri, Kişisel Çalışma Yöntemi, İşverenlerin Zorunluluk Olmadan Engelli İstihdamı, Evde Çalışma Yöntemi, Kooperatif Çalışma Yöntemi ve Sadece Engellilerin Çalıştırıldığı Seçilmiş İşlerde İstihdam Yöntemi oluşturmaktadır. (Selek, Orhan, 2012, s. 38-39).

\section{Kota Sistemi}

Kota sistemi, I. Dünya Savaşı'ndan sonra Avrupa'da uygulanmaya başlamış ve engelli bireylerin kamu ve özel sektör olmak üzere istihdamını teşvik etmek amacıyla belirli oranlarda zorunlu olarak engellilerin istihdamını sağlayan bir sistemi oluşturmaktadır. Bu sistemin önemi ve değeri özellikle II. Dünya Savaşı'ndan sonra daha da artmış ve böylece savaştan gazi olarak dönen askerlerin istihdam edilmesinde kota sistemi'nden faydalanılmıştır. II. Dünya Savaşı'ndan sonraki süreçte kota sisteminin içerisine engelli sivil bireyler de eklenerek kapsamı genişletilmiştir. 
Kota sistemi, Türkiye'de ilk defa 1475 sayılı İş Kanunu ile çalışma hayatının içerisine girmiştir. Ayrıca ilerleyen dönemde yeni iş kanunları ve yasal düzenlemelerle birlikte engelli istihdamı desteklenmeye devam etmiştir. (Orhan,Uysal, 2019, s. 274).

\section{Korumalı İş Yerleri}

Korumalı iş yerleri: "İşü̈cü piyasasına kazandırılmaları güç olan zihinsel veya ruhsal engelli bireylere istihdam oluşturmak amacıyla devlet tarafindan teknik ve mali yönden desteklenen ve çalışma ortamı özel olarak düzenlenen işyeri” olarak ifade edilmektedir. https://www.mevzuat.gov.tr/Metin. Aspx?MevzuatKod=7.5.19050\&MevzuatIliski=0\&sourceXmlSearch= (24.01.2020). Tanımdan da anlaşılacağı üzere korumalı iş yerleri, genel olarak iş hayatına kazandırılmaları güç olan engellilerin istihdamını amaçlamaktadır. Korumalı işyerleri sayesinde yalnızca engellilerin istihdamını kolaylaştırmak hedeflenmemekle birlikte ayrıca engellilerin tedavi edilmelerine ve sosyalleşmelerine de katkı sağlanmaktadır.

\section{Kişisel Çalışma Yöntemi}

Kişisel çalışma yöntemiyle engelli bireyler kendi işyerlerini kurabilmekte ve aynı zamanda eğer mümkünse engelli olmayan bireylere de istihdam olanağ 1 sağlayabilmektedirler. Görüldüğü üzere bu engelli istihdam yöntemiyle birlikte engelli birey hem iş hayatına katılmış olmakta hem de kendi işinin patronu olabilmektedir. (Dursun, Aytaç, 2017, s. 265).

\section{İşverenlerin Zorunluluk Olmadan Engelli İstihdamı}

İşverenlerin zorunluluk olmadan engelli istihdamı sayesinde işverenler kendi istek ve arzuları doğrultusunda kendi işyerlerinde engelli istihdamı sağlayabilmektedirler. Aynı zamanda bu sistemde kota veya ceza uygulamasının olmadığı da bilinmektedir. Bu sistemin bütününü tamamen işverenlerin duyarlılığ engellilerin de iş hayatına katılmalarını bir sorumluluk bilinci olarak düşünmeleri oluşturmaktadır. Ayrıca, Türkiye'de gereklilik olmadığı halde ya da kontenjan fazlası engelli çalıştıran işverenlere de devlet tarafından prim teşviki yapıldığı bilinmektedir. Bu teşvikler 4857 sayılı İş Kanunu'nun 30. maddesinde belirtilmiştir. (Şen, 2018, s. 139). 


\section{Evde Çalışma Yöntemi}

Evde çalı̧̧ma yöntemindeki temel gaye engelli bireyin engel durumuna göre evin bir bölümünün engelliye uygun çalışma ortamına dönüştürülmesidir. Örneğin, işaret dili bilen ortopedik bir engelli evden işitme engellilere bilgisayar ve internet vasıtasıyla kolayca çevirmenlik hizmeti sunabilmektedir. Evde çalışma yöntemiyle ilgi birçok kurum ve kuruluş hibe destekli veya desteksiz birçok projeye imza atarak engellilerin istihdamının önünü açmaya çalışmıştır. $\mathrm{Bu}$ çalışma yönetiminin en güzel uygulamalarından birisini İstanbul Büyükşehir Belediyesi Engelliler Müdürlüğü gerçekleştirmiştir. 2012 yılında kalkınma ajansına sunulan ve kazanılan “İşte Engel yok-Engelli Gençler İstihdam Projesi” ile 286 engelli birey engelleri aşarak çalışma hayatına atılmıştır. https://saglik.ibb.istanbul/iste-engel-yok-projesi-ileengelli-bireyler-is-hayatina-atiliyor/ (28.08.2019).

\section{Kooperatif Çalışma Yöntemi}

Kooperatif çalışma yöntemiyle engelliler kendi imkanlarıyla ve gayretleriyle ya da devlet desteği alarak kendi kurdukları kooperatif şeklinde örgütlenmelerle, farklı çalışma alanlarında kendilerine istihdam olană̆ sağlamaktadırlar. Bu çalışma yöntemini uygulayan ülkeler, kooperatif çalışma yönetimini kendi mevzuatlarına göre düzenlemekte ve desteklemektedir. (Orhan, 2013, s.44-45). Esasen bu yöntem sayesinde engelliler; örgütlenme, bağımsız bir kuruluş olarak faaliyet gösterme, kapasitelerini ölçme ve değerlendirme ve güç birliği gibi çeşitli faydalardan da istifade etmektedirler.

\section{Sadece Engellilerin Çalıştırıldığı Seçilmiş İşlerde İstihdam}

Bu çalışma yöntemini engellilere özel olarak seçilmiş birtakım işlerde sadece engellilerin istihdam edilmesi oluşturmaktadır. Bu çalışma yönteminin bir diğer adı ise "Tahsis Yöntemi”dir. Bu tür istihdam yöntemine göre, engel gruplarının farklılıklarına göre bazı iş kolu ve mesleklerin kısmi olarak veya tamamen engelliler için ayrılmasını veya ayrıştırılmasını istemekte ve öngörmektedir. Zira bu yöntem engelliler tarafindan fazla benimsenmemektedir. Çünkü engellilere göre bu yöntemle engellilerin kendilerine dışlanma hissini verdiğ bilinmektedir. (Genç, Çat, 2013, s. 376-377). 


\section{İstanbul Büyükşehir Belediyesi Engelliler Müdürlüğü ve İstihdam Hizmetleri}

İstanbul Büyükşehir Belediyesi Engelliler Müdürlüğü, 1994 yılında "Özürlüler Koordinasyon Merkezi” olarak kurulmuş olup geçmişten bugüne değin engelli ve ailelerine İstanbul genelinde hizmet etmektedir. Bu anlamda 25 yıllık süre içerisinde müdürlügün hizmet alanları, faaliyetleri ve yapısı büyüme göstermiştir. Engelliler Müdürlüğü, İstanbul'da yaşayan engellilere ve ailelerine yerinde hizmet etmeye çalışmaktadır. Bu doğrultuda günümüzde Engelliler Müdürlüğü’ne ait İstanbul genelinde 30'a yakın Engelli Merkezi, 9 İrtibat Bürosu ve 2 Engelli Kampı bulunmaktadır. https://saglik.ibb.istanbul/ engelliler-mudurlugu/ (27.01.2020).

Engelliler Müdürlügü̈nün genel anlamda amaçları arasında; engellilerin bağımsızlaşmalarına destek olmak, engellilerin çevresel koşullarını iyileştirmek, onların kişisel kapasitelerini arttırmak, üretime katılmalarını ve katkı sağlamalarını gerçekleştirmek, yaşam kalitelerini yükseltmek ve toplumsal gelişmelerden pay almalarına yardımcı olmak bulunmaktadır. https://www.ibb.istanbul/CorporateUnit/Detail/43 (27.01.2020).

Engelliler Müdürlüğü'nün hizmetlerini esasen yedi farklı kategoride değerlendirmek mümkündür. Hizmet kategorilerinin başlıklarını ise, Psiko-Sosyal Servis Hizmetleri, Eğitim Hizmetleri, Ulaşım Hizmetleri ve Çağrı Merkezi, Sağlık Destek Hizmetleri, Toplumun bilinçlendirilmesi Hizmetleri, Engellilere Yönelik Kuaförlük Hizmetleri ve Kamp Hizmetleri oluşturmaktadır. (Tınar, 2018, s. 188-190.)

Sunulan hizmetlerin biraz daha ayrıntısı üzerinde durulması yerinde olacaktır. Psiko-Sosyal Servis Hizmetlerini; sosyal destek hizmetleri (kültürsanat festivalleri, gezi ve eğlence programları, spor etkinlikleri), psikolojik destek hizmetleri (konuşma terapisi, aile eğitim ve seminer çalışmaları, bireysel ve grup psikolojik danışmanlık servisi, aile erken eğitim programı), yasal haklar danışmanlığı ve istihdam destek hizmetleri oluşturmaktadır. (Tinar, 2018, s. 188-189).

Eğitim hizmetlerinin kapsamı içerisinde; zihinsel engelliler beceri kazandırma ve mesleki rehabilitasyon merkezleri, karma eğitim hizmetleri, yaz okulu hizmetleri, Türk işaret dili eğitimleri ve E-KPSS ve hazırlık kursu eğitimleri bulunmaktadır. https://saglik.ibb.istanbul/egitim-hizmetleri/ (27.01.2020). 
Ulaşım hizmetleri ve çağrı merkezi hizmetlerini ise ulaşım hizmetleri ve çağrı merkezi oluşturmaktadır. Bu hizmetle birlikte engellilerin sosyal hayata katılımını sağlamak, engelli ve yakınlarının çalışma hayatını kolaylaştırmak, yakını olmayan veya yakını olduğu halde kendisi ile ilgilenecek durumda olmayan engellilerin güven içinde sokağa çıkmalarını sağlamak, engellilerin ihtiyaçlarını rahatça temin etmelerini sağlamak ve sosyal hayatın içerisinde onların daha fazla yer almaları düşünülmüştür. Ayrıca bu hizmetlerden faydalanmak isteyenlerin öncelikle çağrı merkeziyle iletişime geçmesi gerekmektedir. https://saglik.ibb.istanbul/ulasim-hizmetleri/ (27.01.2020).

Sağlık destek hizmetlerinin içerisinde; hidroterapi hizmetleri, sporla rehabilitasyon hizmetleri, medikal malzeme desteği, medikal bakım-onarım hizmeti ve hipoterapi vardır.

Toplumun bilinçlendirilmesi, yani engellilerin sosyal hayata adaptasyonu veya toplumun engellilere adaptasyonu (ESHA) projesi kapsamında ilk ve ortaöğretim öğrencilerinin engellilik konusunda bilinçlendirilmesi sağlanmaktadır. Aynı zamanda bu projeyle İstanbul'da bulunan diğer kamu kurum ve kuruluşlarında çalışan personellere yönelik olarak da engelli farkındalığg hakkında sunumlar yapılmaktadır. (Karaağaç, 2017, s. 96).

Engellilere yönelik kuaförlük hizmeti sayesinde İstanbul'da ikamet eden, ağır engelli grubunda olan ve evinden genel olarak dişarıya çıkamayan engelliler ücretsiz olarak faydalanmaktadır. (Karaağaç, 2017, s. 87).

Engelli ve yakınlarına yönelik kamp hizmetleri kapsamında; İstanbul'un farklı yerlerinde ikamet eden engelli ve aileleri birer haftalık periyotlarla engelli kamplarına getirilerek 1 hafta süresince tatil yapmaktadırlar. Kamp alanlarında; deniz, sosyal donatı alanları, yemekhane, açık ve kapalı olmak üzere sinema alanları, konferans salonları, kafeteryalar, internet kafeler vb. işlev ve fonksiyonu olan hizmet tesisleri yer almaktadır. https://saglik.ibb. istanbul/kamp-hizmetleri/ (27.01.2020).

Engelliler Müdürlüğü bünyesinde engelli ve ailelerine hizmet vermek amaciyla psikologlar, sosyologlar, çocuk gelişimcileri, özel eğitimciler ve eğitmenler, konuşma dil ve terapistleri, avukatlar gibi meslek elemanları bulunmaktadır. https://www.isper.istanbul/menu/isem-engelliler-merkezi-vebagli-birimler (26.01.2020). 


\section{Engelliler Müdürlüğü İstihdam Destek Hizmetleri}

Engelliler Müdürlügü istihdam destek hizmetlerinin temel hedefini: engelli bireyleri iş hayatına hazırlamak, onların iş bulmalarına aracı olmak ve engelli bireyin sahip olduğu engellerin aşılmasına yardımcı olmak şeklinde sıralayabilmek mümkündür. Ancak müdürlük tarafından yapılması istenilen birkaç hususta bulunmaktadır. Bu hususlardan birkaçını ise engelli bireyin çalışma hayatına katılmak istemesi ve kendine ait özgeçmiş bilgilerini alıp müdürlüğe ait engelli istihdam merkezlerine gelmesi oluşturmaktadır. Engelli bireyin özgeçmiş bilgileri alındıktan sonra kişinin fiziksel ve psikososyal özellikleri dikkate alınarak kişinin kendisine uygun iş olanakları araştırılmaktadır. Böylece kriterlere ve kişilere uyan işlerin bulunmasıyla birlikte işverenlerle irtibata geçilmektedir. Bu iş̧̧i ve işveren buluşmaları toplu olarak belirli zaman araklılarıyla gerçekleşmektedir. Yani engelli bireyin istihdamına aracı olunmaktadır. Ayrıca, çalışma istek ve arzusunda olan engelli bireylerin çalışma hayatına katılımının kolaylaşması için gereken eğitim ve danışmanlık hizmetleri de sunulmaktadır. Bu amaç doğrultusunda 2016 yılında İstanbul Büyükşehir Belediyesi ve Çalışma ve İş Kurumu (İŞKUR) İstanbul İl Müdürlüğü arasında bir protokol imzalanmıştır. İmzalanan protokol sayesinde engelli bireylerin işgücü piyasasına katılımının sağlanmasının kolaylaştı̆̆ 1 da bilinilmektedir. http://www.ibb.gov.tr/tr-TR/Documents/ engelliler_mudurlugu/engellibrosur_2017.pdf(11.07.2019).

Tablo 2

2014-2018 Yilları Arasında Cinsiyete Göre İse Yerleșen Engelli Sayısı

\begin{tabular}{lcccccc}
\hline Cinsiyete Göre İşe Yerleşen Engelliler & $\mathbf{2 0 1 4}$ & $\mathbf{2 0 1 5}$ & $\mathbf{2 0 1 6}$ & $\mathbf{2 0 1 7}$ & $\mathbf{2 0 1 8}$ & Toplam \\
\hline Erkek & 125 & 205 & 285 & 259 & 299 & 1.173 \\
Kadın & 56 & 71 & 70 & 82 & 103 & 382 \\
& & & & & & 1.555 \\
\hline
\end{tabular}

Kaynak: İstanbul Büyükşehir Belediyesi, Engelliler Müdürlüğü İstatistiki Verileri, İstanbul, 2019.

Engelliler Müdürlüğü tarafından cinsiyete göre 2014-2018 yılları arasında istihdam edilen engellilerin toplam sayısı 1.555 kişidir. İstihdam edilen engelliler içerisinde erkeklerin sayısı kadınlara oranla fazla olmuştur. Değinilen yıllar itibariyle engelli istihdamına bakıldığında yine istihdam edilen engelli erkeklerin kadınlardan fazla olduğu görülmektedir. Nitekim işverenlerin engelli istihdamında bu tabloya bakılarak kadınlara nazaran erkek engellilere daha çok ihtiyaç duyduğu veya istihdam ettiği söylenebilmektedir. 
Tablo 3

2014-2018 Yılları Arasında Eğitim Durumuna Göre İşe Yerleşen Engelli Kişi Sayısı

\begin{tabular}{lcccccc}
\hline & \multicolumn{6}{c}{ Eğitim Durumuna Göre İșe Yerleşen Engelli Kişi Sayısı } \\
\hline & $\mathbf{2 0 1 4}$ & $\mathbf{2 0 1 5}$ & $\mathbf{2 0 1 6}$ & $\mathbf{2 0 1 7}$ & $\mathbf{2 0 1 8}$ & Toplam \\
\hline Okula Gitmeyen & 3 & 1 & & & & 4 \\
İlkokul & 29 & 70 & 77 & 74 & 76 & 326 \\
Ortaokul & 47 & 47 & 92 & 81 & 79 & 346 \\
Lise & 79 & 120 & 113 & 124 & 157 & 593 \\
Üniversite & 23 & 43 & 73 & 61 & 83 & 283 \\
Yüksek Lisans & & & & & & 3 \\
& & & & & & 1.555 \\
\hline
\end{tabular}

Kaynak: İstanbul Büyükşehir Belediyesi, Engelliler Müdürlüğü İstatistiki Verileri, İstanbul, 2019.

Yukarıdaki tabloya göre, engellilerin istihdam edilmeleriyle eğitim seviyelerinin doğru veya ters orantılı olmadığı görülmektedir. Bilakis üniversite mezunu istihdam edilen engelli sayısıyla ortaokul veya ilkokul mezunu istihdam edilen engelli sayısı arasında fazla bir fark olmadığı görülmektedir. Yine tablo 3'e göre, okula gitmeyen engellilerin istihdam edilmelerinde pek tercih edilmediği fakat ilkokul ve ortaokul mezunlarının sayı olarak okula gitmeyenlere göre oldukça fazla olduğu bilinmektedir. Ayrıca üniversite mezunlarının da istihdam edilmelerinin kolay olduğu söylenebilmektedir. Toplam istihdam edilen engelliler içerisinde lisansüstü eğitim gören engelli sayısının ise oldukça az olduğu görülmektedir.

Tablo 4

2014-2018 Yilları Arasında Engel Grubuna Göre İşe Yerleşen Kişi Sayısı

\begin{tabular}{lcccccc}
\hline & \multicolumn{6}{c}{ Engel Grubuna Göre İşe Yerleşen Kişi Sayısı } \\
\hline & $\mathbf{2 0 1 4}$ & $\mathbf{2 0 1 5}$ & $\mathbf{2 0 1 6}$ & $\mathbf{2 0 1 7}$ & $\mathbf{2 0 1 8}$ & Toplam \\
\hline Görme & 18 & 50 & 61 & 52 & 61 & 242 \\
İsitme & 22 & 58 & 44 & 48 & 63 & 235 \\
Ortopedik & 66 & 74 & 83 & 97 & 83 & 403 \\
Zihinsel & 30 & 9 & 25 & 29 & 56 & 149 \\
Ruhsal ve Duygusal & & 10 & 14 & 3 & 3 & 30 \\
Süreğen & 40 & 79 & 128 & 113 & 136 & 496 \\
& & & & & & 1.555 \\
\hline
\end{tabular}

Kaynak: İstanbul Büyükşehir Belediyesi, Engelliler Müdürlüğü İstatistiki Verileri, İstanbul, 2019.

Görme, işitme, ortopedik, zihinsel, ruhsal ve duygusal ve süreğen engelliler içerisinde y1llar itibariyle süreğen engellilerin toplam istihdam edilen engelliler arasında en fazla olduğu görülmektedir. Süreğen engellileri istihdam edilebilirlik açısından sırasıyla; ortopedik, görme, işitme, zihinsel ve ruhsal ve duygusal engelliler takip etmektedir. Ayrıca tabloya göre engelli 
istihdamı konusunda ruhsal ve duygusal engellilerin işverenler tarafindan pek tercih edilmediği de söylenebilmektedir.

Tablo 5

2014-2018 Yılları Arasında Yaş Grubuna Göre İşe Yerleşen Engelli Kişi Sayısı

\begin{tabular}{lcccccc}
\hline & \multicolumn{5}{c}{ Yaş Grubuna Göre İşe Yerleşen Engelli Kişi Sayısı } \\
\hline & $\mathbf{2 0 1 4}$ & $\mathbf{2 0 1 5}$ & $\mathbf{2 0 1 6}$ & $\mathbf{2 0 1 7}$ & $\mathbf{2 0 1 8}$ & Toplam \\
\hline $18-24$ & 13 & 18 & 34 & 66 & 54 & 185 \\
$25-35$ & 111 & 136 & 175 & 140 & 204 & 766 \\
$36-45$ & 48 & 90 & 112 & 105 & 107 & 462 \\
$46-55$ & 8 & 33 & 27 & 24 & 32 & 124 \\
56 ve Üstü & 1 & 3 & 5 & 4 & 5 & 18 \\
& & & & & & 1.555 \\
\hline
\end{tabular}

Kaynak: İstanbul Büyükşehir Belediyesi, Engelliler Müdürlüğ̈̈ İstatistiki Verileri, İstanbul, 2019.

Tablo 5'e göre 2014-2018 yılları arasında 18-56 ve üstü yaş grupları arasında 25-35 yaş arası engellilerin toplam istihdam edilenler arasında en fazla olduğu görülmektedir. 25-35 yaş grubundan sonra istihdam açısından en çok tercih edilen yaş grubunun 36-45 olduğu söylenebilmektedir. Yine tabloya ve yaş gruplarına bakılarak 56 ve üstü yaş grubunda olan engellilerin hem yıllar itibariyle hem de toplam istihdam içerisinde en az olduğu görülmektedir.

Tablo 6

2014-2018 Yılları Arasında Alınan Engelli Özgeçmiş Sayısı

\begin{tabular}{lcccccc}
\hline & $\mathbf{2 0 1 4}$ & $\mathbf{2 0 1 5}$ & $\mathbf{2 0 1 6}$ & $\mathbf{2 0 1 7}$ & $\mathbf{2 0 1 8}$ & Toplam \\
\hline Alınan Engelli Özgeçmiş Sayısı & 686 & 1.002 & 1.632 & 959 & 951 & 5.230 \\
İrtibat Kurulan Firma Sayıs1 & & & 320 & 186 & 144 & 650 \\
İstihdam Sağlayan Firma Sayıs1 & & & 255 & 261 & 332 & 848 \\
\hline
\end{tabular}

Kaynak: İstanbul Büyükşehir Belediyesi, Engelliler Müdürlüğü İstatistiki Verileri, İstanbul, 2019.

2014-2018 yılları arasında toplam 5.230 engellinin özgeçmiş bilgisi alınmıştır. Fakat yıllar arasında alınan özgeçmiş sayısında farklılıklar olduğu görülmektedir. Zira en çok özgeçmiş alımı 2016 yılında olurken en az özgeçmiş alımı 2014 yılında gerçekleşmiştir. Yine tabloya göre, Engelliler Müdürlüğü tarafından son üç yıl içerisinde 650 firmayla irtibat kurulmuş ve yine 2016 yılında irtibat kurulan firma sayısı diğer yıllara göre oldukça fazla olmuştur. Engelli istihdamı sağlayan firma sayısı son üç yıl içerisinde toplamda 848 olarak gerçekleşmiştir. Belirtilen yıllar içerisinde en çok engelli istihdamı sağlayan firma sayısı 2018 yılında 332 olarak gerçekleşmiştir. 
Tablo 7

2014-2018 Yılları Arasında Sektörlere Göre İşe Yerleşen Engelli Kişi Sayısı

\begin{tabular}{ccccccc}
\hline Yıllar & $\begin{array}{c}\text { Hizmet(Çağrı } \\
\text { Merkezi, Reyon } \\
\text { Görevlisi vb.) }\end{array}$ & Kamu & Sağlık & Sanayi & $\begin{array}{c}\text { İşe Yerleştirilen } \\
\text { Engelli Sayısı }\end{array}$ & $\begin{array}{c}\text { Çalışılan } \\
\text { Firma Sayısı }\end{array}$ \\
\hline 2014 & 136 & 37 & & 8 & 181 & 120 \\
2015 & 187 & 58 & & 35 & 280 & 175 \\
2016 & 256 & 56 & 17 & 30 & 353 & 195 \\
2017 & 252 & 10 & 29 & 51 & 339 & 179 \\
2018 & 324 & 22 & 6 & 50 & 402 & 248 \\
Toplam & 1.555 & 183 & 52 & 174 & 1.555 & 917 \\
\hline
\end{tabular}

Kaynak: İstanbul Büyükşehir Belediyesi, Engelliler Müdürlüğ̈̈ İstatistiki Verileri, İstanbul, 2019.

Engelliler, iş hayatında hemen hemen her sektörde istihdam edilmektedirler. $\mathrm{Bu}$ açıdan engellilerin istihdamı konusunda atılan önemli adımlar ve çıkarılan yasal düzenlemeler sayesinde engelliler gerek özel sektörde gerekse kamu sektöründe geçmiş yıllara nazaran daha fazla istihdam edilmişlerdir. Engellilerin en çok istihdam edildiği sektör tablo 7'ye göre, daha çok hizmet sektörüdür. Ayrıca yine kamuda engellilerin istihdamı konusunda Engelliler Müdürlüğü tarafindan açılan kurslar vasıtasıyla E-KPSS'ye girerek istihdam edilen engelli sayıs1 183 olmuştur.

\section{Sonuç}

Özellikle 20. yüzyılın son çeyreğinde Türkiye'de belediyeler kendilerinin yapmakla zorunlu olduğu alt yapı, imar, kanalizasyon vb. görevlerin yanında sosyal politikaya ve sosyal belediyeciliğe daha çok önem vermeye başlamıştır. Bu süre zarfından sonra belediyeler, dezavantajlı kesime hizmet eden birimleri kendi bünyelerinde oluşturmaya başlamışlardır. Yine zaman içerisinde belediyeler sosyal anlamda ve alanda çalışmaları daha planlı, sistematik ve kapsamlı bir şekilde yapmaya başlamışlardır.

İstanbul Büyükşehir Belediyesi Engelliler Müdürlüğü, Türkiye'de gerek merkezi yönetim tarafından gerekse diğer belediyeler tarafından engelliler alanında çalışan ve hizmet üreten en önemli kurumlardan birisidir. Engelliler Müdürlügüu, engellilik alanında yapmış olduğu çalışmalar ve yapılan bu çalışmaların genelde Türkiye'de bir ilk olmasından dolayı diğer belediyelere de rol model olmaktadır. Çünkü Engelliler Müdürlügüu, bütçesi, hizmet kalitesi ve standardı, yönetim ve organizasyon şeması vb. özellikleri bünyesinde bulunduran bir müdürlüktür. Bu olgu ve gerekçelerden yola çıkılarak denilebilir 
ki, Engelliler Müdürlüğ̈̈, bazı engelli hizmetlerinde merkezi yönetimin de eksik kaldığı veya tamamlayamadığı hizmetleri yerine getirebilmektedir.

İstanbul Büyükşehir Belediyesi Sağlık Daire Başkanlığı Engelliler Müdürlüğü tarafından engellilere yönelik birçok hizmet üretilmekle birlikte bu hizmetler içerisinde özelde engelli istihdam hizmeti de bulunmaktadır. Esasen engelli istihdamıyla birlikte müdürlük, engelli bireylere ekonomik, psikolojik ve sosyal fayda sağlamaktadır. Nitekim, engelli istihdam hizmeti Engelliler Müdürlügü tarafından profesyonelce planlanmakta ve alanında uzman kişiler tarafindan organize edilmektedir. Ayrıca Engelliler Müdürlüğü, bu yapısal ve organizasyonel hareketler ve hizmetler neticesinde iş arayan engelli bireylere ciddi anlamda yardım sağlamaktadır. Engelliler Müdürlüğü tarafindan bütün bu işçi-işveren buluşmalarının yapılması, psikologlar tarafından bizzat engel grubuna göre engellilerin özgeçmişinin alınması, işin gerektirdiği niteliklere göre özgeçmişlerin filtrelenip işverene ve işe uygun engellilerin bulunması özenle yapılmaktadır. Bunların yanı sıra ücretsiz olarak müdürlük bünyesinde açılan EKPSS kurslarıyla da engellilerin devlet memuru olmalarına katkıda bulunulmaktadır.

Hakem Değerlendirmesi: Dış bağımsız.

Çıkar Çatışması: Yazar çıkar çatışması bildirmemiştir.

Finansal Destek: Yazar bu çalışma için finansal destek almadığını beyan etmiştir.

Peer-review: Externally peer-reviewed.

Conflict of Interest: The author has no conflict of interest to declare.

Grant Support: The author declared that this study has received no financial support. 


\section{Kaynakça/References}

Arıkan, S. ve Ayyıldız, E. (2018). Engelli Bireylerin Destekli İstihdamı. Kocabaş, Ç. içinde, Türkiye'de Engelli Memur İstihdamı (s. 59-91). İstanbul: Akademik Kitaplar.

Çınar, N. (2010). Üniversite Kampüslerindeki Peyzaj Erişebilirliğinin Engelliler Açısından Irdelenmesi, Ankara.

Dursun, S. ve Aytaç, S. (2017). Çalışma yaşamında özel gruplar. Bursa: Ekin Basım Yayım Dağıtım.

Genç, Y. ve Çat, G. (2013). Engellilerin istihdamı ve sosyal içerme ilişkisi. Akademik Incelemeler Dergisi, 8(1), 363-393.

Güleç, Y. (2014). Sosyal hizmetlerin yeniden yapılandırılmasında yerel yönetimlerin önemi ve işlevi, Bağcılar engelliler sarayı örneği. Akademik Sosyal Araştırmalar Dergisi, 1, 486-500.

Henden, B. ve Henden, R. (2005). Yerel yönetimlerin hizmet sunumundaki değişim ve e-Belediyecilik, Elektronik Sosyal Bilimler Dergisi, 4(14), 48-66.

Karaağaç, Ş. (2017). Sosyal Belediyecilik Üzerinden Engellilere Yönelik Hizmetler: İBB Engelliler Müdürlüğü Örneği, Basılmamış Yüksek Lisans Tezi.

İstanbul Büyükşehir Belediyesi. (2012). Özürlüler yerel hizmet rehberi İsöm modeli. İstanbul: İBB Basımevi.

İstanbul Büyükşehir Belediyesi. (2019). Istanbul Büyükşehir Belediyesi Săglık Daire Başkanlığı Engelliler Müdürlüğ̈̈̈ İstihdam Birimi İstatistiki Verileri, İstanbul.

Mamatoğlu, N. (2015). Türkiye'de engelli istihdamının genel görünümü: İşveren gözüyle engelli istihdamını artırma konusunda önerilen politikalar. Alternatif Politika, 7(3), 524-561.

Orhan, S. (2013). Türkiye'de Özürlü Dostu İstihdam Politikalarl (Durum Analizi ve Öneriler). Ankara: Çalışma ve Sosyal Güvenlik Eğitim ve Araştırma Merkezi Yayınları, Yayın No: 35.

Orhan, S. ve Selek, C. (2012). Özürlü istihdam yöntemlerinin uygulanabilirliği üzerine bir değerlendirme. Çalışma İlişkileri Dergisi, 3(2), 36-48.

Orhan, S. ve Uysal, S. (2019). Engelli bireylerin çalışma hayatında maruz kaldıkları duygusal yükler: Sakarya ili örneği. İnsan ve Toplum Bilimleri Araştırmaları Dergisi, $8(1), 271-291$.

Öztürk, M. (2011). Türkiye'de engelli gerçeği. İstanbul: Müsiad Cep Kitapları: 30.

Şen, M. (2018). Türkiye'de Engellilere Yönelik İstihdam Politikaları: Sorunlar ve Öneriler, Sosyal Güvenlik Dergisi, Cilt 8, Sayı 2, 129-152.

T.C. Aile ve Sosyal Politikalar Bakanlığı. (2017). 2016 Yılı Faaliyet Raporu, Ankara.

Tınar, Y. (2018). Engellilere yönelik kamu hizmetlerinin yönetimi ve sunumu: Karşılaştırmalı bir değerlendirme. İstanbul: Hiperyayın.

Tiyek, R. (2014). Yerel sosyal politika bağlamında “İş’te Engel Yok Projesi”. Sosyal Siyaset Konferanslarl, 66-67, 101-126. 


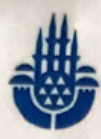

Say1 : 76947147-120.02-

Konu : Talep

T.C.

ISTANBUL BÜYÜKȘEHIR BELEDIYE BASSKANLIĞI

Sağlık Daire Başkanlığı

Engelliler Müdürlüğü

12. $04: 2019$

Sayın Yaşar TINAR

İlgi : :09.04.2019 tarihli dilekçeniz.

İlgi dilekçenizde bahsi geçen Sosyal Servis Şefliği İstihdam Birimi tarafindan yürütülen hizmetlere ait istatistiki veriler ekte sunulmuştur.

Bilgilerinizi ve gereğini rica ederim.

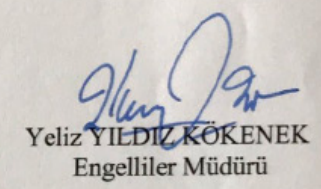

Ek : Dosya(1 Adet)

Istanbul Büyuukşsehir Belediye Başkanlığı Kasımpaşa Ek Hizmet Binası Hacıahmet Mah. Muhsin Yazıcıoğlu Cad.

No:1 34440 Beyoğlu/ISTANBUL

e-posta:isem@ibb.gov.tr Elektronik Ağ: www.ibb.gov.tr

Telefon: $02124499660-61$ Faks: 02124495034

Ek 1. İstanbul Büyükşehir Belediyesi Engelliler Müdürlüğü’nden alınan verilere erişim izin belgesi 
